Article

\title{
Synergy of the (Campus) Commons: Integrating Campus-Based Team Projects in an Introductory Sustainability Course
}

\author{
Charlotte R. Clark ${ }^{1, *(1)}$ and Tavey M. Capps ${ }^{2}$ \\ 1 Nicholas School of the Environment, Duke University, Durham, NC 27710, USA \\ 2 Office of Sustainable Duke, Duke University, Durham, NC 27710, USA; tavey.mcdaniel@duke.edu \\ * Correspondence: cclark@duke.edu
}

Received: 17 December 2019; Accepted: 4 February 2020; Published: 8 February 2020

\begin{abstract}
Faculty and staff at Duke have collaborated to teach a one-semester, introductory, undergraduate course on sustainability ten times over 12 years, including both theoretical and applied project-based content. This article describes the overall process and rhythm of the course, and provides a unique contribution by summarizing our process to accomplish on-campus sustainability projects where three- to five-person student teams collaborate with on-campus clients throughout the semester, researching questions posed by the client, and ultimately providing recommendations. The faculty/staff partnership on the instructional team permits five to six projects to be designed each year, with a much broader array of clients and authentic research questions than could be envisioned by an academic faculty member alone. Having a strong connection with the Sustainable Duke staff provides the trust with other staff on campus that project results can endure past the semester time period if warranted.
\end{abstract}

Keywords: undergraduate; experiential education; team-based; campus; transdisciplinary sustainability education; interdisciplinary sustainability education; faculty collaboration; campus as a living laboratory; service learning; project-based learning

\section{Introduction}

Student learning at the undergraduate level benefits from a number of components that are pertinent to the topic of sustainability. For example, requiring students to complete a major, or a series of courses in both sequential and synchronous order, provides breadth and depth in a particular discipline; many institutions of higher education (IHE) now have majors, minors, or certificates in sustainability. That said, evidence exists that, even in a single course, exposure to a wide variety of scholarly approaches, both natural and social sciences in particular, can be more important than continued exposure to one approach through multiple courses [1]. Second, connecting classroom learning to real-world problems and solutions, thereby connecting the theoretical to the applied, has been shown to anchor learning [2]. Assignments that work to solve sustainability issues within a student's own geographic and residential context give students confidence that change is possible, provide improvement to their community, and illustrate normative progress beyond the actual campus [3]. Third, where learners have the option to situate their learning in cultural, historical, and geographic aspects that are proximate to the learner, the learning has been shown to be more firmly anchored than when issues are distant [4]. Where that learning is accomplished using campus environs as the laboratory for the research question, the accomplishment of campus sustainability goals can be accelerated concurrently $[5,6]$. Finally, co-curricular and informal learning that happens concurrently with formal classroom education at the undergraduate level has been shown to have a high value. 
In fact, Falk et al. contend that Americans spend less than five percent of their life in classrooms, and that most science is learned outside of formal school settings [7]. Using case studies, project and/or problem-based learning, and place-based environmental education can synergistically connect sustainable development pedagogical approaches to competences [8]. These components collectively argue for repetition and depth of content, emphasize the impact of learning outside the classroom, and beg the question of whether or how material on sustainability presented in a single class for one semester can have value for undergraduate learning.

This article describes an introductory undergraduate class entitled Sustainability Theory and Practice (Duke course code SUSTAIN245), which is designed to facilitate learning and research among students that confronts the interconnections between environmental, economic, and social aspects of sustainability. A core focus of the course, which has been offered 10 times over the last 12 years, is to help students learn to apply interdisciplinary systems thinking in service to society professionally and in civic life after they graduate. In this context, systems thinking means that students consider not only constituent parts of various environmental and human systems, but also how these systems work over time, space, and scale.

This course was developed at Duke in three phases, corresponding to an evolving perception of need. First, the course was titled "Food and Energy," and was developed by faculty from the realization that sustainable food systems were of increasing interest to students on campus, that no course existed to discuss this important topic, and that the founding faculty herself had much to learn on the subject. That is, it evolved in part from an honest realization that many adults are disconnected from their food system, and this has strong sustainability implications. The course always had campus-based, client-based project teams as an important component, because of our belief in the strength of experiential and place-based learning, and within a few years, we decided to branch out from projects that were just about food, and to include other topics as relevant. At this point, the course name was changed to "Sustainability Theory and Practice." Food-related projects were included each year, and the broader scope still filled a content void on the Duke campus for undergraduates. Concurrently, the University's Campus Sustainability Committee was working to implement the American College and University President's Climate Commitment [9], which included a commitment to infuse climate neutrality and sustainability throughout the educational experience of all students. Thus, acknowledging that Duke did not have a major or minor in Sustainability, a faculty and staff team worked to gain approval for an undergraduate Certificate in Sustainability Engagement, and SUSTAIN245 became the gateway course for that Certificate. In short, the need for this course started as faculty followed student interest in sustainable food systems, broadened to include all issues of sustainability, and now serves as the anchor for a Certificate by which students, regardless of major, can have a sustainability credential on their transcript.

Key learning outcomes of the course are:

1. Analyze the structure, components, and processes of natural, economic, and social systems and the interconnections between and interdependency of these systems.

2. Evaluate complex trade-offs between different dimensions of sustainability and their impact on the sustainability of the system.

3. Effectively engage with stakeholders about sustainability challenges using best practices, including collaboration, cooperation, and reciprocity.

4. Create and implement strategies to enhance the sustainability of such systems.

A number of articles have described specific aspects of college and university courses on sustainability, including student outcomes; specific focus areas; various types of pedagogy, instructional teams, and course structure; different depths or timelines; and locations on- and off-campus [2,10-13]. Exploring individual components divorced from their function in a larger system is insufficient, as it truncates critical relationships between parts of the integrated system. SUSTAIN245 uses local, primarily campus-based, projects in collaboration with real-world clients to support both undergraduate learning about sustainability, and true improvement for sustainability outcomes on a college campus. 
This article aims to bring to previous literature a specific process by which undergraduates can accomplish on-campus sustainability projects as a part of a one-semester course, and to provide examples of the breadth of specific on-campus clients and research questions we have designed. Although off-campus experiences can be inspiring and informative, many logistical and financial barriers are reduced if on-campus experiences can accomplish significant curricular goals.

This course is based on a theoretical framework of both place-based ecology education, and experiential, project-based, learning theory. Place-based, or place-centered, education contends that using local places to achieve sustainability goals addresses twin goals of local geo-literacy, and broader goals in sustainability that can be applied to other geographic settings-that is the local exemplar provides an infrastructure allowing the student to transfer the learning to other settings $[14,15]$. The assumption here is that becoming a thoughtful and active citizen of the place where we live supports engagement with future places of residency, and even world locations that might connect with the values of a person without co-location [16]. Experiential learning theory suggests a cycle where students experience something tangible and concrete, reflect on that experience (individually or in a group), conceptualize that experience in a more abstract fashion, and actively experiment with the concept within the original experience and outside it [17]. Further, using project-based learning, especially when partnered with a client and a problem that truly matters to the client, has been shown to increase pro-environmental attitudes and intention to choose a sustainable lifestyle [18].

Thus, although theory is a significant component of the class, this paper will focus on the applied and experiential component-three- to five-person student teams that work on a problem throughout the semester with real-world, largely campus-based, clients. Over the past several years, Sustainable Duke has been considering opportunities for a broader "Campus as Lab" (CAL) initiative, which views the physical campus as a "living laboratory," where students explore real-world issues, while tackling institutional sustainability challenges.

We will describe how the class is structured overall, situating the theory and lecture class components with the student projects. We will describe the students' projects, as well as other components such as the development of research skills, student assessment, and use of field experiences and guest lectures, and will include components that have worked well and are retained, and others that worked less well and have been discarded. We will identify the specific projects that we have studied and implemented, suggesting for each the level of impact of the student conclusions. Our hope is that our list of historical team projects (see Appendix A) will be useful and inspirational to those on other campuses, and that our lessons learned will support relevant faculty/staff collaborations at other institutions of higher education (A copy of the most recent syllabus is available from the corresponding author).

\section{Materials and Methods}

SUSTAIN245, "Sustainability Theory and Practice," was created to provide curricular content on sustainability for Duke University undergraduates, regardless of major, and from its inception was linked to practical projects on Duke's campus researched by student teams during the semester. For the first three years, the course focused on the intersection of food and energy, and then was broadened to sustainability in general. In 2015, Duke approved the undergraduate Certificate in Sustainability Engagement, and the course serves as a "gateway" course to the Certificate, meaning that it must be one of the first requirements accomplished by students wishing to earn the Certificate credential (At Duke, a Certificate is one of three types of programs an undergraduate student can complete, the others being a major and a minor. Each student must complete a major, and may choose to complete up to two other programs, such as another (double) major, a major and minor, a major and certificate, etc.). The course meets twice a week for 75 minutes, for approximately 15 weeks.

We have limited registration to between 24 and 30 students, as a function of time needed to develop and support the team projects. In the early years, the course filled quickly, so students were primarily juniors and seniors with the earliest priority registration windows. When the Certificate was approved, 
and this course was named the gateway, we wanted to ensure that registration was available to firstand second-year students, who had the most potential to also complete the Certificate. Therefore, we set limits on upperclass student registration to ensure that at least half the spots were available for first- and second-year undergraduates. The class has typically been a fairly even mix of men and women. Approximately one-third to one-half students had not yet declared a major, and the remainder are a mix of majors in an environmental field, in Trinity College (liberal arts, non-environmental field), and in the Pratt School of Engineering (see Figure 1). We had a master's level teaching assistant each semester.

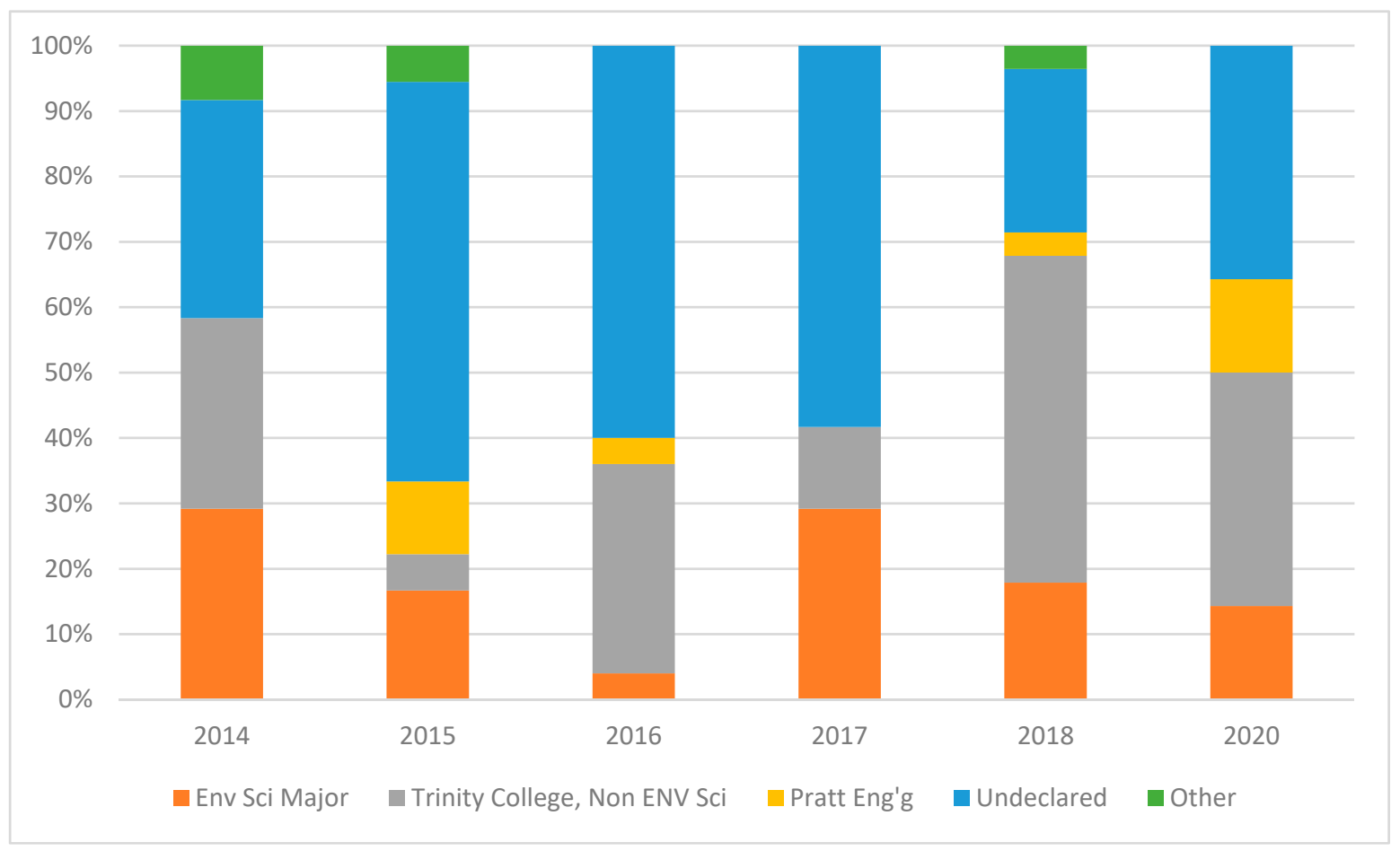

Figure 1. SUSTAIN245 Majors by Year, 2014-2020.

Because we particularly want to engage first- and second- year students in the Certificate, we promote the Certificate and the course in a number of relevant ways each year. First, we provide sessions that are optional during the orientation week for first year students in August. Second, the Office of Sustainable Duke promotes the course on their website, with their interns and volunteer students, and in their weekly newsletter. Third, in the early spring each year, we table at the Majors Fair, an event where each Department or program who wishes provides materials at a large hall of co-located tables. Finally, in April each year, high school seniors who are accepted, but have not made their final college decision, attend "Blue Devil Days" on campus, where we also provide materials to students and their parents at tables. Wherever possible, we request and retain names and email addresses, and use these to remind students about the class during times when students plan for and register for classes for the upcoming semester.

The class has three primary types of content: research design and implementation; sustainability theory and application at the campus, local/regional, national, and international scales; and a small team project. About one-third of the class meetings are traditional lecture style, although we ensure that some time for interactive discussion is always included. Another third is planning and progress meetings for the individual teams; we have small breakout rooms available that are co-located, and allow the instructors to cycle among the team meetings during the class period. The final third of the courses are activity-based classes, such as team management exercises, an activity to understand collective action and common pool goods; or one to practice analysis of qualitative data, particularly when working 
in teams. The course has a "research" designation at Duke (students are required to have a certain number of courses with this designation during their four years), because the projects all require data collection and analysis. These data are mostly qualitative, such as interviews, observations, focus groups, and open-ended survey questions, although some teams have implemented questionnaires, which typically are exploratory in design, without representative sampling, nor generalizability to a larger population. Content on sustainability theory includes definitional and historic readings, and consideration of a number of frameworks, such as ISO26000, Global Reporting Initiative, the UN Sustainable Development Goals, B Corps, and the UN Global Compact. We endeavor to include consideration of sustainability in governmental, non-governmental, and corporate institutions. Guest lectures are provided by relevant scholars from Duke's Nicholas School of the Environment, but also from other departments such as the Divinity School (faith perspectives), and the School of Public Policy (policy and economic aspects). Other speakers are from on-campus facilities personnel (water, energy, transportation, etc.), or external corporate sustainability officers.

\subsection{Relationship of Team Projects with Sustainable Development Outcomes}

The class content is designed around two concepts of competence-action competence and strategic competence. Action competence in environmental education works at the nexus of factual knowledge, interpretation of knowledge, and commitment to change to result in particular action choices [19]. Strategic competence for sustainability functionally links literacy, skills, and attitudes to support successful problem solving, but also requires that these components be applied to true problems and challenges [20]. Linking these two, we endeavor to require that students can articulate and critique various definitions of sustainability, can describe various contexts where others work to institutionalize these definitions (government, corporate, not for profit), and also have experienced the opportunities and challenges to apply these concepts to a real-world situation on (or near) campus.

In the team-based projects, we explicitly engage with the five sustainability competencies named by Wiek et al. [20] Each project engages the first, systems thinking competence through requirements that environmental, social, and economic components are explicitly considered by the students and the client during the semester, and that tradeoffs among the components, and between costs and benefits are acknowledged, and prioritization assumptions named. Anticipatory competence surfaces as students work with their client(s) to incorporate short and long-term costs and benefits, the need to evaluate success and failure, and consideration of uncertainty. In recent years, we realized that although in class we had discussed normative competence, or concepts of risk, ethics, justice, power, etc., we had not strategically incorporated that into the team projects. In 2020, we require that students produce a stakeholder analysis, and consider environmental justice concepts in their teamwork too. The fourth competence named by Wiek et al. is strategic competence, meaning the concept of planning with intentionality, including adaptation, mitigation, and synergies. Teams discuss these concepts throughout their planning phase, checking in with their client on their design and initial findings at mid-points during the semester. Finally, Wiek et al. names interpersonal competence, which is experienced in the teamwork specifically. We see this as teams evaluate the strengths and weaknesses of their individual effort (their own and their teammates) through mid- and end-of-term peer reviews; and we ask teams to evaluate their success as a team also.

\subsection{Student Assessment}

The final grade is composed of 65 percent individual work and 35 percent work on the team project.

The individual proportion includes five components. Early in the semester, students complete four research practica exercises: an observation, an interview, individual certification to do human subjects research, and collection of secondary material $(4 \%)$. Four times during the semester, students must complete a reflection on the readings for a particular day, uploading the reflection to a forum area of the online class website before class begins. This not only helps ensure class preparation, but provides a "crowd-sourced" study guide for the final exam (16\%). Students produce a mid-term exam focused on 
organizational social responsibility $(10 \%)$. Specifically, they find one online institutional annual report ("corporate social responsibility" or other name) for an organization of interest to them, and evaluate it against a number of metrics, including ISO26000, the Global Reporting Initiative, B Corps, and the sustainability development goals. A final exam, weighted 20 percent of their grade, includes multiple and short-answer questions covering the semester's content. Finally, class participation is 15 percent of the individual grade, and includes preparation for and engagement in-class discussion, quality completion of peer evaluations, and participation in identified "field trips." For example, students complete one workday at the Duke Campus Farm, and volunteer with waste-free events, such as football, basketball, or waste audits. Students complete the International Sustainability Literacy Test at the beginning of the semester, and during the final exam, but this is for their and our information only, and is not used as a proportion of their grade.

Teams submit assignments that build on each other, and that permit feedback from the instructional team and client informing the two final products - a brief video and a 4-page project brief. Team projects have three graded components. First, teams must complete a literature review, which typically includes benchmarking against similar questions on other campuses of institutions of higher education; a video storyboard; and a project plan document (5\%). We ask each team member to find at least three unique online or library resources to contribute to their team's literature review; these are placed in a folder visible to all team members, the client, and the instructional team. Second, 10 percent of the grade produces the initial results sent to clients, including an individual and team data analysis exercise, the first cut at a video, and a draft project brief. We provide a template for the brief (see Supplementary Material 1). The third component $(20 \%)$ is the final submitted project brief and video. Students have access to a rubric for each element; Supplementary Material 2 contains the rubric for the video as an example. Supplementary Material 3 contains an example final project brief; its accompanying final video can be viewed at this link: https:/tinyurl.com/SUSTAIN245herpvideo.

\subsection{Course Assessment}

Assessing the success of this course currently has three mechanisms. First, Duke's Trinity College encourages all students to complete a standard course evaluation form at the end of the semester. Second, we track the extent to which student projects make a tangible change on sustainability on campus, both at the end of the semester, and longer term. Third, the Duke standard evaluation has a few open-ended questions for students to complete. Although the prompts for these open-ended questions have not remained entirely consistent year after year, example questions include (a) "Please comment on the course dynamics," (b) "Please comment on your overall course appraisal," or alternatively "Would you like to provide any other comments about this course," and (c) "What would you like to say about this course to a student who is considering taking it in the future."

\subsection{Team Project Process and Description}

The small-team projects have four phases, each of which corresponds to approximately a calendar month in the semester. First, students are introduced to sustainability history, theory, and ethics; research design and implementation concepts are also presented in this phase. In the second week, all clients present during a "speed pitch" session, taking about 10 minutes to describe their unit on campus, the question they wish to pose, why this question is important/interesting to them, and how they are envisioning students will proceed (what kinds of data they might gather, what types of support can the client provide, etc.). Students then complete a preference form that includes not only their priority choices of projects, but other information, such as what types of team roles they are interested in, whether they are comfortable approaching individuals for an interview, whether they have a car, or other questions; these vary each semester with the needs of the particular projects. After students are assigned to projects, we have University staff come in to do team-building exercises, such as using the Clifton StudentStrengths ${ }^{\mathrm{TM}}$, a process that suggests what an individual's strengths are, and enables a team of people to collaboratively assess what strengths are present or perhaps missing. At the end of 
the first month, in lieu of meeting as a whole class, each team meets for an hour with the instructors for a tailored design session, beginning to think about resources in hand and needed, specific team roles for individuals, timeline, types of data to gather, etc. Small research preparatory assignments, or practica, include obtaining individual certification to do human subjects research (an online training), and completing an observation and an interview. The instructors set up a shareable online folder for each team; this is accessible by the student team, the instructors, and the client.

The second phase emphasizes the research design and data collection. Teams are given class time to meet together about once a week, and a member of the instructional team circulates among the teams to answer questions. Almost every research question over the years includes some benchmarking against other campuses that might provide ideas or exemplars relevant to our question. Students use resources, such as the AASHE STARS program, the Green School listserv, or in Duke's case, the IvyPlus sustainability consortium, to gather comparative benchmarking data. At the end of the second month, clients join their team for a discussion of the initial plan and design. At this time, clients and teams readjust expectations, learn what other helpful resources might be needed, and ensure that the planned direction is mutually agreeable and doable. Prior to this client design meeting, teams submit a draft design document to the instructors for assessment and feedback.

The third phase emphasizes data analysis and initial findings/recommendations for the teams. Teams continue to meet during class a part of each week, but may use this time to collect and analyze data, and also frequently conduct additional team meetings outside of class time. We provide specific instruction in class on how to analyze qualitative data individually and in teams. Teams submit a draft analysis assignment to the instructors, where each team member has analyzed at least two pieces of independent data (two interviews, an observation and an interview, etc.). These are graded and returned, and again at the end of the month, the clients join their team for a meeting about initial findings and recommendations. Knowing that good practice is never to surprise a client, the purpose of this meeting is for the client to learn what the team is initially finding, and how they are beginning to form recommendations as a result. Clients play a vital role here to keep a balance between creativity and innovation, and to include the realities of campus timelines and budgets.

In the fourth month, which typically only includes a few last class sessions, the teams finalize their two client deliverables, and then meet a fourth and final time with the client to present their final project. The teams must produce two team deliverables:

1. A four-page visually appealing "project brief," that contains a combination of text, headings, images, and data to summarize their work.

2. A short (2-4 $\mathrm{min})$ video aimed at a particularly relevant audience.

We have implemented more than 55 projects over the life of the course, which we have categorized for this article (see Table 1). Note that projects often fit multiple categories, but we have tried to choose the primary one. We highlight individual projects for each category in the results section below. A complete list of projects, organized by content category, is contained in Appendix A. 
Table 1. Project categories for SUSTAIN245.

\begin{tabular}{ll}
\hline \multicolumn{1}{c}{ Category } & No. of Projects (2009-2020) \\
\hline 1. Operations & 2 \\
\hline a. $\quad$ Energy & 2 \\
\hline b. $\quad$ Landscape & 3 \\
\hline c. $\quad$ Transportation & 7 \\
\hline d. $\quad$ Waste & 2 \\
\hline e. $\quad$ Water & 15 \\
\hline 2. Food ${ }^{1}$ & 7 \\
\hline 3. Literacy and behavior & 6 \\
\hline 4. Campus locations and residences & 5 \\
\hline 5. Carbon offsets & 6 \\
\hline 6. Community (off-campus) & 2 \\
\hline 7. Other & 57 \\
\hline
\end{tabular}

${ }^{1}$ The category "food" has many projects, because (for the first three years of the course) all projects focused on the intersection of food and energy.

\section{Results}

This section will return to the five sustainability competencies named by Wiek et al. [20], will present one or more project examples for each category named above in Table 1, will describe student and course assessment results, and will discuss limitations and challenges.

Our course addresses all five competencies from Wiek et al. [20] with varying degrees of success. We see success in all five when considering the course as a whole with all components, but see the level of success as more uneven when considering the role of the projects independent of the other course components. Students engage strongly with systems thinking in the course overall and in the projects alone, because the research process requires them to consider complex tradeoffs, such as achievable short-term versus aspirational long-term goals; knowledge of those with shorter tenure on campus (students) compared to faculty and staff with longer tenure; budget tradeoffs; and changing technologies, politics, and "appetite" for certain types of change on campus.

Anticipatory competence is also seen both in the course as a whole, as well as in the projects alone. Each project must be planned in consideration of what can be accomplished during less than one semester, and includes suggestions of what could happen after the students' work is completed. Both the in-semester work, and the post-semester suggestions must be sensitive to realities of constraint, resources, uncertainty, and probability.

Normative competence provides the highest area for improvement in our course going forward. Although the theoretical, lecture content, and individual work aspects of the course require strong consideration of concepts of justice, safety, fairness, etc. (such as through study of the components of ISO26000, the UN Sustainable Development Goals, or the Global Reporting Initiative), we need to improve this competence for the team-based projects. In 2020, we will assign discussion topics during some of the times when teams are meeting in their small groups during class time. Such topics could include producing a stakeholder analysis, engaging the topic of environmental justice more strongly, reading articles about culturally responsive evaluation, and considering their own positionality in the research.

Both strategic and interpersonal competence are woven strongly through the course as a whole, and through the project work specifically. Projects must consider path (and alternate path(s)), transition, intervention, and alliance. Further, the teams must evaluate their work at various points, both through 
assigned peer assessments, through explicit team discussion, and through preparation for client meetings. Descriptions of specific projects will illustrate these points.

\subsection{On-Campus Operations Projects}

The most frequent category for campus sustainability projects in SUSTAIN245 has involved operational aspects of sustainability, specifically energy (2 projects), landscape (2 projects), transportation ( 3 projects), waste (7 projects), and water ( 2 projects), or a total of 16 projects.

How can we green the electronic printing (ePrint) experience at Duke? [Category: Waste (2013)]. Client, Duke Office of Information Technology.

Duke's Office of Information Technology, in conjunction with Duke libraries (where most ePrint stations are located) asked students to research whether a "hard quota" or limit on student printing would not only benefit the University's sustainability objectives, but would be approvable on campus. The students recommended a system whereby a soft quota (no charge) would be followed by a hard quota with printing charged directly to a student's account, accompanied by education and incentives for good behavior. Subsequent to the recommendations by the SUSTAIN245 team, the effort was continued by a team of graduate and undergraduate students, staff of OIT and the library, and the Duke Student Government. Changes to the quota system became official in Fall 2014, showing the importance of continued staff diligence after the course is complete for some projects [21].

How might Duke maintain campus landscape spaces most sustainably: The Environment Hall 'front yard' as a case study. [Category: Landscape operations (2016)]. Client, Duke Campus Horticulturist

Students researched landscape options that would work for the needs of public spaces on Duke's campus, including consideration of price, seasonality, maintenance, aesthetics, and safety. Also, students studied two pilot areas on campus where native grasses had been planted in lieu of turf grass, comparing the maintenance needs, and the response to the look by passersby. Students found that opinion by the public using the pilot areas varied widely from strong appeal to strong dislike, resulting in recommendations for education on this front as well.

\subsection{Food Projects}

Fifteen projects in SUSTAIN245 have focused on food, including eight specifically emphasizing eateries on campus, six concerning the Duke Campus Farm, and one looking at food insecurity on campus.

Duke Campus Farm: A sequence of six projects. [Category: Food (2010, 2011, 2014, 2015, 2018, 2020)] Clients: Duke Campus Farm staff.

The initial project in the Fall of 2010 asked the students to conduct a feasibility study only, but the ambitious student team gained permission by the end of the semester to plow and plant a meadow site in the Duke Forest; currently, the Farm has four full-time staff members, a 10-member student farm crew, hundreds of student volunteer participants at semi-weekly workdays, and grows thousands of pounds of produce for a Community Supported Agriculture membership, Duke Dining, and campus events. Institutional and foundational support has allowed infrastructure improvements such as a commercial walk-in refrigerator, a wash-and-pack operation, and a covered pavilion for teaching and events such as contra dancing. The six farm projects have ranged from student recruitment to expansion of growing area to creation of an edible wind break and a medicinal herb garden. In 2020, a student team will examine how to welcome animals (specifically laying hens) to the Farm.

Food Insecurity on Campus: What do we know and what might Duke do? [Category: Food (2016)] Clients: Director of Nutrition Services, Director of Planning, Duke World Food Policy Center. 
Students interviewed faculty and staff at Duke and at other institutions of higher education about the perception of the prevalence of the problem, and possible responses that the institutions could take. They also observed use of several food banks on and off campus. The project brief recommended approaches that seemed most likely to address the issues on Duke's campus, and the video aimed to increase awareness for this issue (https://inyurl.com/SUSTAIN245foodvideo).

\subsection{Literacy and Behavior Projects}

Literacy and behavior change has been the focus of seven projects in SUSTAIN245. We are always careful to acknowledge that what one knows, what one intends to do, what one reports that happens, what one is observed doing, and what can be measured are all very different outcomes. Further, we emphasize that learning something is not necessarily a precursor to doing something; learning and behavior change theories are complex.

The Healthy Duke Initiative: What is the wellness-sustainability connection? [Category: Literacy and behavior (2017)]. Client: Assistant Dean/Director, Duke Student Wellness Center.

Much has been written about the ways that natural and beautiful built spaces can contribute to better health. Students researched this connection, and the ways that other institutions of higher education use such spaces to reduce stress and increase mental and physical health, compiling an inventory of such campus locations that are easily accessible to students. They also produced a video (https://tinyurl.com/SUSTAIN245healthrideo) to introduce these locations to students and to promote their use.

How can Duke motivate composting by dining customers beyond putting signage directly on or near the composting bins themselves? [Category: Literacy and behavior (2018)] Clients: Assistant Director for Duke Dining Sustainability; Recycling and Waste Reduction Coordinator.

Two specific campus dining locations were chosen as case study sites, both of which were piloting post-consumer composting. The students observed behavior at the two sites, and conducted brief intercept interviews of students and staff. Recommendations included training of dining staff (specific training points were provided), signage at the point of sale tailored to the products sold at that dinery, and other creative ideas that would appeal to students. The students produced a humorous video to appeal to a student audience (video link https://tinyurl.com/SUSTAIN245compostvideo).

How can education staff at the Sarah P. Duke Gardens best infuse concepts of sustainability into the implementation of elementary school field trip programs held on site? [Category: Literacy and behavior. (2018)] Client: Education Director, Sarah P. Duke Botanic Gardens

Students observed elementary school field trips, interviewed education staff at the Gardens, and analyzed current curricular content. They produced suggestions for modifications to existing and options for new curricula, and produced a video recruiting students to volunteer at the Gardens (https://tinyurl.com/SUSTAIN245gardenvideo)

\subsection{Campus Locations and Residences Projects}

Although all our projects focus on some specific location(s) on campus, six projects were very geographically-based, and centered on increasing sustainability in specific venues on campus, beyond those already counted in the food/dinery category. For example, students have worked in Duke Forest, Duke Health System, Duke residence halls, and outdoor locations that could become resources for "Campus as Laboratory" activities.

How can Duke institutionalize the growing "Campus as Lab" movement in higher education? [Category: Campus locations and residence halls (2017)] Client: University Landscape Architect 
The client requested that three specific on-campus sites be used as case studies: The Duke Water Reclamation Pond, the Medical Center Greenway, and a stream restoration project. Students analyzed records of current student and course use, observed use by persons on campus, and researched campus as lab initiatives at other institutions. Recommendations were made for ways to recruit use of each site for formal courses, research work by students and faculty, and appropriate recreational activities.

How can Duke Forest use citizen science to better understand and conserve the herpetofauna population in the Forest? [Category: Campus locations and residence halls (2017)]. Clients: Director and Associate Director, Duke Forest.

North Carolina has particular prevalence and richness of amphibians and reptiles in the US, which are also key indicators of climate change effects on wildlife. By looking at other citizen science programs, and gathering data on volunteer interests and capacities, the students recommended training sessions, data collection and sharing methods, and volunteer engagement techniques. Students produced an informative project brief (https://tinyurl.com/SUSTAIN245herpbrief) and a promotional video (https://tinyurl.com/SUSTAIN245herpvideo). Staff of the Duke Forest have subsequently implemented a citizen-science herpetofauna program, using many of the student's recommendations.

\subsection{Carbon Offsets Projects}

Duke has a Carbon Offsets Initiative within the Office of Sustainable Duke, which has served as a client for five team projects in SUSTAIN245. Duke signed the American College and University President's Climate Commitment (ACUPCC) [9] in 2007, leading to a Campus Sustainability Plan, a Sustainability Strategic Plan, and an institutional commitment to being carbon neutral by 2024 . Subsequently, the University created the Duke Carbon Offsets Initiative (DCOI), whose mission is to enable accomplishment of that goal, to help Duke become a model carbon neutral institution, and to lead peer institutions in similar efforts. For example, a project in 2015 specifically targeted office behaviors that would reduce electricity use by staff.

What information should Duke's Carbon Offsets Initiative include in energy conservation educational resources for staff to increase factual knowledge, support new and improved skills or competencies, and lead to behavior change that decreases energy use? [Category: Carbon offsets (2014)]. Client: Program Manager, Duke Carbon Offsets Initiative.

Students researched existing resources on campus, looked at peer institutions for other ideas, and recommended exemplary promotional activities that the client could institute. The students also created a promotional video (https://tinyurl.com/SUSTAIN245officevideo).

\subsection{Community Projects}

Five projects have worked with community partners, located largely off Duke's campus proper, such as working with the City of Durham, local K-12 institutions, and in one case, an international competitive entrepreneurial challenge.

How can students and the community best address the problem of invasive cankerworms killing trees on and near campus? [Category: Community (2014)]. Clients: Natural Resource Manager, Duke Facilities Management; Durham City Arborist]

Students learned about the process of banding trees to interfere in the cankerworm life cycle, and made recommendations for which are the most sustainable and cost-effective materials for this job. They also observed several community training events, and made recommendations, including an educational video (https://tinyurl.com/SUSTAIN245wormvideo), for ways the City and Duke campus could increase the number of volunteers doing banding operations. 
Should Durham pursue an ecodesignation model of development, such as Eco-Districts, 2030 Districts, or Living City Block? [Category: Community (2015)]. Client: Sustainability Manager, Durham City and County.

Students compared three ecodesignation models available to municipalities, recommending how each of the three might have applicability for the City and County of Durham

\subsection{Student and Course Assessment Results}

Course assessment will be reported from three perspectives. The first measure, shown in Table 2, provides average student evaluation for the last five years on a set of fourteen quantitative items. All items are above 3.0 on a 5.0 scale, with a total average response of 3.71 ( $\mathrm{n}=87$ responses of 119 students, or $73 \%$ response rate).

Table 2. Average student course evaluation responses (academic years 2015-2019).

\begin{tabular}{cc}
\hline \multicolumn{2}{c}{ Scale: 1 (Lowest) To 5 (Highest) } \\
\hline Overall course & 3.77 \\
\hline Overall instructor & 4.24 \\
\hline Amount of work & 3.27 \\
\hline Difficulty & 3.01 \\
\hline Intellectual stimulation & 3.90 \\
\hline Clearly defined learning objectives & 3.53 \\
\hline Gaining factual knowledge & 3.69 \\
\hline Learning to apply knowledge, concepts, principles, or theories to a \\
specific situation or problem. & 3.91 \\
\hline Learning to analyze ideas, arguments, and points of view & 3.96 \\
\hline Learning to synthesize and integrate knowledge & 3.61 \\
\hline Learning to conduct an inquiry through methods of the field & 3.85 \\
\hline Learning to evaluation the merits of ideas and competing claims & 4.26 \\
\hline Percent of class submitting evaluation responses & 3.63 \\
\hline
\end{tabular}

The second measure of course success is the ability of student projects to make a tangible change in sustainability on campus. Appendix A provides a complete list of all projects completed in the course, with a qualitative estimate of project impact on campus sustainability objectives.

The third measure of course success is seen in answers students provided to open-ended questions on the University end-of-course course evaluation. Although most of the comments are positive and encouraging, two particular types of comments have led to significant and beneficial course changes. The next paragraphs will provide some of the verbatim student answers on these topics.

Predominantly, student comments were positive regarding the impact the course and projects had on their understanding and attitudes:

This class will teach you more than factual knowledge. The service-learning component ... will teach you how to solve problems and conduct research in the real world.

The course will definitely give you an in-depth knowledge and comprehension of sustainability, the difficulties of handling it, and the overall pros.

I feel that the semester-long project really built up an intellectual community in the class that is not common at Duke. 
This course will help you become more conscientious [with regard to] the choices you make about sustainability every single day

You learn skills and you get to apply them through the class projects, rather than just learning theoretical concepts.

Constructive critique about course content primarily revolved around connecting the readings to lecture content, particularly when guest speakers were brought in, including connecting guest speakers to each other.

The final is going to be challenging, because we have never tried to put the speakers in conversation with each other...

Some of the readings didn't seem to connect to class discussions. I wish there was more of a connective flow in the classes/guest lecturers ...

The assigned readings were often never really emphasized beyond the theory-based lectures. Maybe find a way to work them into the project work?

I felt like the [instructors] should consider weekly reflections or writing assignments to keep students [on] track.

In response, we instituted three changes. First, we added a requirement that students post reflections on the readings prior to class at least four times over the semester. Specifically, they are asked to (1) highlight a compelling theme or idea in the readings, (2) put at least two of the readings in conversation with each other, and when relevant, with other weeks' readings, and (3) raise at least one key point or question for discussion. These are posted to a public forum on the class website so that the instructional team and all students can read them. Second, we have made a more deliberate effort to use class discussion each day to connect speakers to each other and to the readings. Third, on the days when groups meet in their teams during class time, we have begun asking that they use at least 15 minutes of the period to discuss a particular prompt that we provide to relate that content to their particular project specifically.

Students often chafe with working in teams for the project. Some of this discomfort seems a useful part of the process of learning to work in teams.

Depending on your role and project, you may have to interact with a lot of people/do a lot of organization

Watch out! Lots of extra time required on the group project which can be frustrating.

It's also incredibly important to take the project seriously, and coordinating with group members will take a lot of effort.

You can get really lucky or really unlucky depending on your group project and your assigned group.

Other comments about teamwork led to changes in the course that could lead to better team preparation and management on the part of the instructors.

In the future have more guidance for the group projects

I think it is important for the professors to pay attention to different group dynamics because that is a huge factor in whether the project gets done well or not.

... the instructors could have done a better job ensuring that all students put forth the same amount of work.. 
The course could be better if the students learned more about the other projects ... I felt that I was so concentrated on my own project which caused me to not learn/grasp any knowledge from ... the other student projects.

We have worked to address such comments in several ways. In team formation, we have added questions to our project preference form that go beyond simple interest in the topic, and address leadership style, availability outside of class (or immovable constraints), interest in visioning versus details, etc. In 2020, we will pilot the use of the CATME TM platform for some of these non-project related questions. Immediately upon teams being announced, we also provide a Clifton StudentStrengths ${ }^{\mathrm{TM}}$ assessment in class, where students not only see how the tool suggests their own strengths, but also spend facilitated time in-class discussion the collective strengths of their newly formed team. To work towards a more fair and equitable effort split into teams, we require mid- and end-of-semester peer reviews, which both impact the final participation grade of a team member based on their team's responses about them, and impact their own final participation grade based on the thoughtfulness of their own reviews of others. In 2020, we will pilot the use of the CATME ${ }^{\mathrm{TM}}$ platform for these reviews. Finally, we now have two times in the semester where class time is used for each project to make an informative presentation on their progress, surprises, successes, and challenges.

\subsection{Limitations and Challenges}

Limitations and challenges exist for the course design and implementation, and for the study itself. With regard to the course deliverables, in early years, we had the teams produce collaboratively written research papers, but found that these were not only difficult to produce in teams (often leading to team effort inequities), but also less useful to the client than a brief. We now provide a 4-page PowerPoint template to delimit format for the brief. Because videography experience varies widely, we try to spread any student expertise among the teams, and support this deliverable with (a) technical support and advice from a professional campus videographer, and (b) an early team assignment to create a video storyboard.

We would like to increase class size to reach more students, but have kept the cap at 30 students to allow for teams of no more than five students, and no more than six teams a semester. We are open to learning of ideas to retain the client-centered, place-based approach to the team projects, while increasing class size.

A constant challenge is keeping the projects reasonably scoped to the timeframe, while working on the twin goals to engage students with authentic goals, and provide a true benefit to the client. Clients have constraints of mentoring limits, and limits to implementation based on money, time, institutional structure/silos, etc. For example, our project to recommend a green dinery concept to the Duke Health System, although worthy, was perhaps premature, because it was not accomplished at a time when the institution was truly ready to implement such a costly change. On the other hand, aspirational projects can reach higher than imagined; the feasibility study to consider a Duke Campus Farm led within the semester to permission for students to use a one-acre plot in Duke Forest for food production, and within the year to the plot being plowed and cover-cropped in readiness for its first seeding.

The purpose of this paper is largely exploratory and descriptive. However, looking to future research, many avenues exist by which research on this course or others of its type could be stronger and broader. In-depth interviews of a sample of participating students each year would add depth to the understanding of the student experience and course impact. Future evaluation of the course would benefit from interviews of the clients, including immediately after the semester and from a more longitudinal standpoint, such as six months or a year after the semester has concluded. Criteria could be established by which certain projects were chosen as case studies, and wider data collection could be accomplished, such as interviews beyond the clients, observation of impacts, surveys of participating students or staff, and secondary data, such as articles in campus or wider media. A broader reach might be accomplished by benchmarking this class with like classes at other institutions of higher education, perhaps creating a "library" of place-based, client-centered project ideas to which others 
could contribute that would be publicly accessible. A model for this could be the "Curriculum for the Bioregion" initiative created by Jean MacGregor in Washington State [16].

\section{Discussion}

We identify five aspects of SUSTAIN245 at Duke University that enable this one-semester class to accomplish both theoretical academic goals and practical campus sustainability improvement goals. First, the course is an engaged, long-term collaboration between a faculty member and the Director of Sustainable Duke. The faculty member has ultimate responsibility for the design, content, assessment, and student communication. The Director of Sustainable Duke is the primary liaison between the course and the campus projects, including their development, semester-long implementation, and follow-on actions after the course is complete. This partnership has been essential, because the Director has the network and relationships to ensure that the questions posed are of authentic interest to the on-campus clients and can help the University reach goals in the institutional Sustainability Strategic Plan, and because the faculty member ensures that student learning goals are set and accomplished. The faculty member would not have been able to imagine, much less create, projects with the breadth of topic and client that we have accomplished over these 12 years. Second, the projects must develop designated student skills - in this case research, writing, presentation, team participation and management, and client communication-while not overburdening the clients. Clients must understand and be committed first to student learning, even at the expense of outcomes for their area of responsibility. That said, close attention by the instructional team has been able to typically achieve worthwhile outputs for the clients as well. Third, the deliverables must document student effort, but in a way that is useful for clients. We moved from only a typical written research paper to a system of two more useful deliverables-a four-page, visually appealing project brief, and a two- to four-minute video-combined with an end-of-term presentation to the client. Both of these deliverables are discussed by the team and client on several occasions throughout the semester, to ensure that both parties have the same expectations. Fourth, the project work is contextualized throughout the semester through broad readings about aspects of sustainability (including its history, domestic and international theory and policies), discussion of implementation at different levels (including personal, campus, national, and international), consideration of multiple types of institutions, such as governmental, corporate, and non-governmental. Finally, after each semester is complete, the Director of Sustainable Duke has a particular role in following up with clients to see what else might be needed to continue to move the topic forward. This could result in additional class projects, or completely different momentum, such as advocating for policy changes, such as printing limits, or staff hiring, such as on the Duke Campus Farm.

In sum, specifically through the addition of campus-based project work in this class, we believe that students who succeed in the course can describe their own experience working to accomplish progress towards an on-campus sustainability goal; can design and implement steps to research, prioritize, and evaluate steps towards future goals in their professional lives; and are better prepared to work in teams towards complex goals requiring both individual effort and team-based consensus and adaptation.

Supplementary Materials: The following are available online at http://www.mdpi.com/2071-1050/12/3/1224/s1, Supplementary Material 1: Project brief template, Supplementary Material 2: Video rubric, Supplementary Material 3: Example project brief.

Author Contributions: C.R.C. and T.M.C. collaboratively authored and edited this manuscript. All authors have read and agreed to the published version of the manuscript.

Funding: This research received no external funding.

Conflicts of Interest: The authors declare no conflict of interest. 


\section{Appendix A}

\begin{tabular}{llll}
\hline Research Question & Category & Client & Campus Success/Impact \\
\hline $\begin{array}{l}\text { How can sustainability be infused } \\
\text { into the new housing model on } \\
\text { Duke's West Campus? (2013) }\end{array}$ & $\begin{array}{l}\text { Campus locations and } \\
\text { residence halls }\end{array}$ & $\begin{array}{l}\text { Dean of Residence Life; } \\
\text { Associate Vice Provost } \\
\text { for Undergraduate } \\
\text { Education }\end{array}$ & Medium \\
\hline $\begin{array}{l}\text { What are the primary ways that } \\
\begin{array}{l}\text { Duke Forest contributes to } \\
\text { sustainability at Duke? (2016) }\end{array}\end{array}$ & $\begin{array}{l}\text { Campus locations and } \\
\text { residence halls }\end{array}$ & $\begin{array}{l}\text { Director and Associate } \\
\text { Director, Duke Forest }\end{array}$ & High \\
$\begin{array}{l}\text { How can Duke Forest use citizen } \\
\text { science to better understand and } \\
\begin{array}{l}\text { conserve the herpetofauna } \\
\text { populations in the Forest? (2017) }\end{array}\end{array}$ & $\begin{array}{l}\text { Campus locations and } \\
\text { residences }\end{array}$ & $\begin{array}{l}\text { Assistant VP for Student } \\
\text { Affairs and Dean for } \\
\text { Residential Life }\end{array}$ & High \\
\hline
\end{tabular}

How can Duke institutionalize the growing "Campus as Lab" movement in higher education?

Campus locations and residences
Director and Associate Director, Duke Forest

High (2017)

What is the impact of existing campus residence halls on Duke's sustainability footprint and what specific projects can Housing and Residential Life implement to enhance student experience and conserve resources? (2018)

Expanding and institutionalizing Duke University Health System sustainability efforts. (2020)

Campus locations and residences
Program Coordinator,

Sustainable Duke;

Campus locations and residences
Assistant VP Student Low

Affairs and Dean for

Residential Life
Program manager,

Patient Safety and

Clinical Quality Officer, Duke Health System

Director of Sustainable

Duke; Associate Director,

Duke Carbon Offsets

Medium

Initiative

In process

offset air travel by
and staff? (2013)

Carbon offsets

Program Manager, Duke

Carbon Offsets Initiative

Medium

Energy and carbon offsets: Creating resources for Duke University staff.

Carbon offsets (2014)

What type of carbon offset projects

are other ACUPCC schools undertaking, and what can Duke

Carbon offsets

Program Manager, Duke

Carbon Offsets Initiative

High

learn? (2014)

What is the Duke Carbon Offsets Initiative: Assessing and raising awareness among Duke

Program Manager, Duke

undergraduate students? (2016)

Considering local impact, connections with students/faculty, carbon reduction, and cost, what carbon offset projects are most feasible and appealing for the Duke University Marine Laboratory to pursue? (2018)

Carbon offsets
Program Manager, Duke Carbon Offsets Initiative;

Professor of

Medium

Oceanography, Duke

Marine Lab
Medium

Carbon offsets 


\begin{tabular}{|c|c|c|c|}
\hline Research Question & Category & Client & Campus Success/Impact \\
\hline $\begin{array}{l}\text { How can Lakewood Elementary } \\
\text { School better integrate the } \\
\text { community garden with classroom } \\
\text { instruction and the NC Standard } \\
\text { Course of Study? (2011) }\end{array}$ & Community & $\begin{array}{l}\text { Garden Coordinator, } \\
\text { Lakewood Elementary } \\
\text { School }\end{array}$ & Medium \\
\hline $\begin{array}{l}\text { The Acara Institute Challenge: Plan } \\
\text { a socially-minded business to } \\
\text { address issues of food insecurity in } \\
\text { India. (2011) }\end{array}$ & Community & $\begin{array}{l}\text { Associate Professor, Civil } \\
\text { and Environmental } \\
\text { Engineering, Duke }\end{array}$ & Low \\
\hline $\begin{array}{l}\text { Should Durham pursue an } \\
\text { ecodistrict model of development, } \\
\text { such as Eco-Districts, } 2030 \text { Districts, } \\
\text { or Living City Block? (2015) }\end{array}$ & Community & $\begin{array}{l}\text { Sustainability Manager, } \\
\text { Durham City and } \\
\text { County }\end{array}$ & Low \\
\hline $\begin{array}{l}\text { Should Durham consider a bike } \\
\text { share program? (2015) }\end{array}$ & Community & $\begin{array}{l}\text { Transportation Demand } \\
\text { Manager, Duke Parking } \\
\text { and Transportation; } \\
\text { Bicycle and Pedestrian } \\
\text { Coordinator, City of } \\
\text { Durham }\end{array}$ & High \\
\hline $\begin{array}{l}\text { Feasibility study for composting at } \\
\text { the NC School of Science and } \\
\text { Mathematics. (2016) }\end{array}$ & Community & $\begin{array}{l}\text { Instructor, } \\
\text { Environmental Science, } \\
\text { NCSSM }\end{array}$ & Medium \\
\hline $\begin{array}{l}\text { Save our trees! Battling the } \\
\text { cankerworms. (2015) }\end{array}$ & Community & $\begin{array}{l}\text { Natural Resource } \\
\text { Manager, Duke Facilities } \\
\text { Management; Durham } \\
\text { City Arborist }\end{array}$ & High \\
\hline $\begin{array}{l}\text { How should Duke reward/award } \\
\text { dineries that work to provide local } \\
\text { foods? (2009) }\end{array}$ & Food & $\begin{array}{l}\text { Director, Sustainable } \\
\text { Duke; Director, Center } \\
\text { for Environmental } \\
\text { Farming Systems }\end{array}$ & High \\
\hline $\begin{array}{l}\text { Should Duke have an on-campus } \\
\text { farm? (2010) }\end{array}$ & Food & $\begin{array}{l}\text { Director, Duke Dining; } \\
\text { Campus Landscape } \\
\text { Architect }\end{array}$ & High \\
\hline $\begin{array}{l}\text { How well is the farmstand working } \\
\text { in the Great Hall? (2010) }\end{array}$ & Food & $\begin{array}{l}\text { Manager, Bon Appetit; } \\
\text { Coordinator, Honey } \\
\text { Patch Community } \\
\text { Garden }\end{array}$ & Medium \\
\hline $\begin{array}{l}\text { How can Aramark design and } \\
\text { operate "greener" dineries in the } \\
\text { Duke University Hospital? (2010) }\end{array}$ & Food & $\begin{array}{l}\text { General Manager, Food } \\
\text { Services, Duke } \\
\text { University Hospital; } \\
\text { Director, Sustainable } \\
\text { Duke }\end{array}$ & Low \\
\hline $\begin{array}{l}\text { What is the most sustainable shrimp } \\
\text { purchasing choice Duke dineries } \\
\text { could make? (2010) }\end{array}$ & Food & $\begin{array}{l}\text { Founders, Walking Fish } \\
\text { and DukeFish }\end{array}$ & Medium \\
\hline $\begin{array}{l}\text { What impact does a visit to the } \\
\text { Duke Immersive Virtual } \\
\text { Environment (DiVE) have on } \\
\text { student understanding of } \\
\text { environmental sustainability in the } \\
\text { Duke dining experience? (2011) }\end{array}$ & Food & $\begin{array}{l}\text { Assistant Vice-President, } \\
\text { Communication Services; } \\
\text { Marketing Manager, Bon } \\
\text { Appetit; Director, } \\
\text { Visualization Technology } \\
\text { Group }\end{array}$ & Low \\
\hline
\end{tabular}




\begin{tabular}{|c|c|c|c|}
\hline Research Question & Category & Client & Campus Success/Impact \\
\hline $\begin{array}{l}\text { What will make student } \\
\text { involvement with the new Duke } \\
\text { Campus Farm vibrant and } \\
\text { sustainable? (2011) }\end{array}$ & Food & $\begin{array}{l}\text { Duke Campus Farm } \\
\text { Manager }\end{array}$ & High \\
\hline $\begin{array}{l}\text { How might Clean Air Cool Planet } \\
\text { best accomplish food purchase } \\
\text { behavior change on campus? (2011) }\end{array}$ & Food & $\begin{array}{l}\text { Carbon Accounting } \\
\text { Coordinator, Clean } \\
\text { Air-Cool Planet; } \\
\text { Outreach Coordinator, } \\
\text { Sustainable Duke }\end{array}$ & Medium \\
\hline $\begin{array}{l}\text { Sourcing the Clean } 15 \text { locally at } \\
\text { Duke. (2014) }\end{array}$ & Food & $\begin{array}{l}\text { Outreach Coordinator, } \\
\text { Sustainable Duke; } \\
\text { Assistant Director Duke } \\
\text { Dining }\end{array}$ & Medium \\
\hline $\begin{array}{l}\text { Cultivation of a medicinal herb } \\
\text { garden at the Duke Campus Farm. } \\
\text { (2014) }\end{array}$ & Food & $\begin{array}{l}\text { Duke Campus Farm } \\
\text { Manager }\end{array}$ & Medium \\
\hline $\begin{array}{l}\text { Feasibility study of creating an } \\
\text { edible windbreak at the Duke } \\
\text { Campus Farm. (2015) }\end{array}$ & Food & $\begin{array}{l}\text { Duke Campus Farm } \\
\text { Manager }\end{array}$ & Medium \\
\hline $\begin{array}{l}\text { Food insecurity on campuses: What } \\
\text { do we know and what might Duke } \\
\text { do? (2016) }\end{array}$ & Food & $\begin{array}{l}\text { Director of Nutrition } \\
\text { Services; Director of } \\
\text { Planning, Duke World } \\
\text { Food Policy Center }\end{array}$ & High \\
\hline $\begin{array}{l}\text { Assessing and engaging student } \\
\text { interest in a second site for the Duke } \\
\text { Campus Farm. (2018) }\end{array}$ & Food & $\begin{array}{l}\text { Assistant Program } \\
\text { Manager, Duke Campus } \\
\text { Farm }\end{array}$ & High \\
\hline $\begin{array}{l}\text { Exploring the greenhouse gas } \\
\text { impact of food on campus. (2020) }\end{array}$ & Food & $\begin{array}{l}\text { Duke Green Dining } \\
\text { Coordinator }\end{array}$ & In process \\
\hline $\begin{array}{l}\text { Assessing the feasibility of animals } \\
\text { at Duke Campus Farm. (2020) }\end{array}$ & Food & $\begin{array}{l}\text { Field Education } \\
\text { Coordinator, Duke } \\
\text { Campus Farm }\end{array}$ & In process \\
\hline $\begin{array}{l}\text { How do we assess environmental } \\
\text { literacy at Duke? (2013) }\end{array}$ & Literacy and behavior & $\begin{array}{l}\text { Director of Academic } \\
\text { Assessment, Trinity } \\
\text { College; Outreach } \\
\text { Coordinator, Sustainable } \\
\text { Duke }\end{array}$ & Medium \\
\hline $\begin{array}{l}\text { Improving Duke's green checklist } \\
\text { certification program: How can we } \\
\text { sustain momentum? ((2017) }\end{array}$ & Literacy and behavior & $\begin{array}{l}\text { Program Coordinator, } \\
\text { Sustainable Duke }\end{array}$ & High \\
\hline $\begin{array}{l}\text { The Health Duke Initiative: What is } \\
\text { the wellness-sustainability } \\
\text { connection? (2017) }\end{array}$ & Literacy and behavior & $\begin{array}{l}\text { Assistant Dean/Director, } \\
\text { Duke Student Wellness } \\
\text { Center }\end{array}$ & Medium \\
\hline $\begin{array}{l}\text { Integrating sustainability into school } \\
\text { field trips for elementary-aged } \\
\text { students at the Sarah P. Duke } \\
\text { Botanic Gardens. (2018) }\end{array}$ & Literacy and behavior & $\begin{array}{l}\text { Education Staff, Sarah P. } \\
\text { Duke Botanic Gardens }\end{array}$ & High \\
\hline $\begin{array}{l}\text { Impacting waste management } \\
\text { behavior choices through signage } \\
\text { and staff training in Wilson Gym } \\
\text { and Sanford School of Public Policy. } \\
\text { (2018) }\end{array}$ & Literacy and behavior & $\begin{array}{l}\text { Assistant Director, Duke } \\
\text { Dining Sustainability; } \\
\text { Recycling and Waste } \\
\text { Reduction Coordinator }\end{array}$ & Medium \\
\hline
\end{tabular}




\begin{tabular}{|c|c|c|c|}
\hline Research Question & Category & Client & Campus Success/Impact \\
\hline $\begin{array}{l}\text { Infusing sustainability into Duke } \\
\text { University Admissions (2018) }\end{array}$ & Literacy and behavior & $\begin{array}{l}\text { Associate Director of } \\
\text { Admissions }\end{array}$ & Medium \\
\hline Greening events at Duke. (2020) & Literacy and behavior & $\begin{array}{l}\text { Duke Special Events } \\
\text { Program Manager }\end{array}$ & In process \\
\hline $\begin{array}{l}\text { Should Duke consider building an } \\
\text { on-campus biodiesel refinery to } \\
\text { burn Duke's waste vegetable oil for } \\
\text { use in fleet vehicles? (2010) }\end{array}$ & Operations: Energy & $\begin{array}{l}\text { Recycling and Waste } \\
\text { Reduction Coordinator }\end{array}$ & Low \\
\hline $\begin{array}{l}\text { Assessing and impacting residence } \\
\text { hall electricity demand. (2016) }\end{array}$ & Operations: Energy & $\begin{array}{l}\text { Energy Manager, Duke } \\
\text { Facilities Management }\end{array}$ & Low \\
\hline $\begin{array}{l}\text { How might Duke maintain campus } \\
\text { landscape spaces most sustainably: } \\
\text { The Environment Hall "front yard" } \\
\text { as a case study? (2016) }\end{array}$ & Operations: Energy & $\begin{array}{l}\text { Duke Campus } \\
\text { Horticulturist }\end{array}$ & Low \\
\hline $\begin{array}{l}\text { Redesigning the Environment Hall } \\
\text { orchard. (2017) }\end{array}$ & Operations: Landscape & $\begin{array}{l}\text { Co-President, Nicholas } \\
\text { School Green Roof and } \\
\text { Orchard Workforce } \\
\text { (GROW) }\end{array}$ & Low \\
\hline $\begin{array}{l}\text { Developing an electric vehicle } \\
\text { policy for Duke. (2013) }\end{array}$ & $\begin{array}{l}\text { Operations: } \\
\text { Transportation }\end{array}$ & $\begin{array}{l}\text { Transit Planner, Duke } \\
\text { Parking and } \\
\text { Transportation Services }\end{array}$ & Medium \\
\hline $\begin{array}{l}\text { Peer benchmarking study of } \\
\text { university/hospital parking cash-out } \\
\text { programs. (2015) }\end{array}$ & $\begin{array}{l}\text { Operations: } \\
\text { Transportation }\end{array}$ & $\begin{array}{l}\text { Transportation Demand } \\
\text { Manager, Duke Parking } \\
\text { and Transportation } \\
\text { Services }\end{array}$ & Medium \\
\hline $\begin{array}{l}\text { Opportunities for reducing or } \\
\text { offsetting Duke air travel. (2020) }\end{array}$ & $\begin{array}{l}\text { Operations: } \\
\text { Transportation }\end{array}$ & $\begin{array}{l}\text { Director, Duke Carbon } \\
\text { Offsets Initiative }\end{array}$ & In process \\
\hline $\begin{array}{l}\text { Should Duke compost any organic } \\
\text { food waste on campus? (2009) }\end{array}$ & Operations: Waste & Recycling Coordinator & High \\
\hline $\begin{array}{l}\text { What is the best to-go container to } \\
\text { offer for use in Duke dineries? } \\
\text { (2009) }\end{array}$ & Operations: Waste & $\begin{array}{l}\text { Green Purchasing } \\
\text { Coordinator; Manager, } \\
\text { Bon Appetit }\end{array}$ & High \\
\hline $\begin{array}{l}\text { How can we green the electronic } \\
\text { printing (ePrint) experience at } \\
\text { Duke? (2013) }\end{array}$ & Operations: Waste & $\begin{array}{l}\text { Assistant Director, } \\
\text { Centralized Device } \\
\text { Service and Support, } \\
\text { Duke Office of } \\
\text { Information Technology }\end{array}$ & High \\
\hline $\begin{array}{l}\text { How can Duke best implement } \\
\text { single-stream recycling and } \\
\text { post-consumer composting in } \\
\text { dorms (Part I)? (2013) }\end{array}$ & Operations: Waste & $\begin{array}{l}\text { Recycling and Waste } \\
\text { Reduction Coordinator; } \\
\text { Associate Dean for East } \\
\text { Campus }\end{array}$ & High \\
\hline $\begin{array}{l}\text { Multi-stream recycling and } \\
\text { composting pilot in Duke residence } \\
\text { halls (Part II). (2014) }\end{array}$ & Operations: Waste & $\begin{array}{l}\text { Recycling and Waste } \\
\text { Reduction Coordinator; } \\
\text { Associate Dean for East } \\
\text { Campus }\end{array}$ & High \\
\hline $\begin{array}{l}\text { Expanding waste management at } \\
\text { Duke: Assessment of paper towel } \\
\text { composting in campus buildings. } \\
\text { (2015) }\end{array}$ & Operations: Waste & $\begin{array}{l}\text { Recycling and Waste } \\
\text { Reduction Coordinator }\end{array}$ & High \\
\hline
\end{tabular}




\begin{tabular}{|c|c|c|c|}
\hline Research Question & Category & Client & Campus Success/Impact \\
\hline $\begin{array}{l}\text { Assessing and reducing disposables } \\
\text { in campus dining (2017) }\end{array}$ & Operations: Waste & $\begin{array}{l}\text { Assistant Director, Duke } \\
\text { Dining Sustainability }\end{array}$ & Medium \\
\hline $\begin{array}{l}\text { Should trays be removed in the } \\
\text { Great Hall? (2009) }\end{array}$ & Operations: Water & $\begin{array}{l}\text { Green Dining } \\
\text { Coordinator; } \\
\text { Sustainability Outreach } \\
\text { Coordinator }\end{array}$ & High \\
\hline $\begin{array}{l}\text { More than utility: Educational, } \\
\text { recreational, and research uses of } \\
\text { the new Duke Water Reclamation } \\
\text { Pond. (2013) }\end{array}$ & Operations: Water & $\begin{array}{l}\text { Campus Landscape } \\
\text { Architect; Director of } \\
\text { Grounds; Engineer, Duke } \\
\text { Utilities and Engineering } \\
\text { Services }\end{array}$ & High \\
\hline $\begin{array}{l}\text { Students, faculty, and a local artist } \\
\text { produce a piece of public art on } \\
\text { campus using sustainable materials. } \\
\text { (2013) }\end{array}$ & Other & $\begin{array}{l}\text { Assistant Professor of } \\
\text { Visual Art; local } \\
\text { environmental artist }\end{array}$ & High \\
\hline $\begin{array}{l}\text { Inspiring Duke undergraduates for } \\
\text { careers in sustainability. (2020) }\end{array}$ & Other & $\begin{array}{l}\text { University Career Center; } \\
\text { Nicholas School of the } \\
\text { Environment Career and } \\
\text { Professional Center }\end{array}$ & In process \\
\hline
\end{tabular}

\section{References}

1. Fisher, P.B.; McAdams, E. Gaps in sustainability education: The impact of higher education coursework on perceptions of sustainability. Int. J. Sustain. High. Educ. 2015, 16, 407-423. [CrossRef]

2. Brundiers, K.; Wiek, A.; Redman, C.L. Real-world learning opportunities in sustainability: From classroom into the real world. Int. J. Sustain. High. Educ. 2010, 11, 308-324. [CrossRef]

3. Rowe, D. Education for a Sustainable Future. Science 2007, 317, 323-324. [CrossRef] [PubMed]

4. Miller, H.K. Undergraduates in a sustainability semester: Models of social change for sustainability. J. Environ. Educ. 2015, 47, 52-67. [CrossRef]

5. Safitri Zen, I. Exploring the living laboratory: An approach to strengthen campus sustainability initiataives by using sustainability science approach. Int. J. Sustain. High. Educ. 2017, 18, 939-955.

6. Bacon, C.M.; Mulvaney, D.; Ball, T.A.; DuPuis, E.M.; Gliessman, S.R.; Lipschutz, R.D.; Shakouri, A. The creation of an integrated sustainability curriculum and studwnt praxis projects. Int. J. Sustain. High. Educ. 2011, 12, 193-208. [CrossRef]

7. Falk, J.H.; Dierking, L.D. The 95 Percent Solution. Am. Sci. 2010, 98, 486-493. [CrossRef]

8. Lozano, R.; Merrill, M.Y.; Sammalisto, K.; Ceulemans, K.; Lozano, F.J. Connecting Competences and Pedagogical Approaches for Sustainable Development in Higher Education: A Literature Review and Framework Proposal. Sustainability 2017, 9, 1889. [CrossRef]

9. ACUPCC American College and University Presidents Climate Commitment. 2014. Available online: http://www.secondnature.org/wp-content/uploads/Carbon-Commitment-2017-Second-Nature.pdf (accessed on 7 February 2020).

10. Brekken, C.A.; Peterson, H.H.; King, R.P.; Conner, D. Writing a recipe for teaching sustainable food systems: Lessons from three university courses. Sustainability 2018, 10, 1898. [CrossRef]

11. Coops, N.C.; Marcus, J.; Construt, I.; Frank, E.; Kellett, R.; Mazzi, E.; Munro, A.; Nesbit, S.; Riseman, A.; Robinson, J.; et al. How an entry-level interdisciplinary sustainability course revealed the benefits and challenges of a university-wide initiative for sustainability education. Int. J. Sustain. High. Educ. 2015, 16, 729-747. [CrossRef]

12. Dmochowski, J.E.; Garofalo, D.; Fisher, S.; Greene, A.; Gambogi, D. Integrating sustainability across the university curriculum. Int. J. Sustain. High. Educ. 2016, 17, 652-670. [CrossRef]

13. Remington-Doucette, S.M.; Hiller Connell, K.Y.; Armstrong, C.M.; Musgrove, S.L. Assessing sustainability education in a transdisciplinary undergraduate course focused on real-world problem solving. Int. J. Sustain. High. Educ. 2013, 14, 404-433. [CrossRef] 
14. Duffin, M.; Perry, E.E. Regional Collaboration for Sustainability via Place-Based Ecology Education: A mixed-methods case study of the Upper Valley Teaching Place Collaborative. Educ. Sci. 2019, 9, 6. [CrossRef]

15. Sobel, D. Place-Based Education: Connecting Classrooms \& Communities; Orion Society: Great Barrington, MA, USA, 2004.

16. MacGregor, J. Curriculum for the Bioregion: Learning to Live Sustainably in Our "Life Places". Appl. Environ. Educ. Commun. 2005, 4, 239-243. [CrossRef]

17. Kolb, D.A. Experiential Learning: Experience as the Source of Learning and Development, 2nd ed.; Prentice-Hall: Englewood Cliffs, NJ, USA, 1984; Volume 1.

18. Perrault, E.K.; Albert, C.A. Utilizing project-based learning to increase sustainability attitudes among students. Appl. Environ. Educ. Commun. 2018, 17, 96-105. [CrossRef]

19. Fontes, P.J. Action competence as an integrating objective for environmental education. Can. J. Environ. Educ. 2004, 9, 148-162.

20. Wiek, A.; Withycombe, L.; Redman, C.L. Key competencies in sustainability: A reference framework for academic program development. Sustain. Sci. 2011, 6, 203-218. [CrossRef]

21. Clark, C.R. Collective action competence: An asset to campus sustainability. Int. J. Sustain. High. Educ. 2016, 17, 559-578. [CrossRef]

(C) 2020 by the authors. Licensee MDPI, Basel, Switzerland. This article is an open access article distributed under the terms and conditions of the Creative Commons Attribution (CC BY) license (http://creativecommons.org/licenses/by/4.0/). 